\title{
IN VITRO AND IN VIVO STUDY OF EFFECT OF LEMON JUICE ON URINARY LITHOGENESIS
}

\author{
Abdelkhalek Oussama, Mohamed Touhami and Mohamed Mbarki.
}

Laboratoire de Spectrpchimie Appliquée et Environnement, Unité d'Urolithiase, Faculty of Sciences and Technices of Béni-Mellal. University CADI AYYAD. Morocco.

Summary.- OBJECTIVES: The diversity of experimental results obtained in the study of the effect of citrus juice on urinary lithogenicity moved us to study the effect of these substances in vitro and in-vivo. The in-vitro study is based on the turbidimetric method on calcium oxalate crystallization. In vivo, we studied the effect of lemon juice consumption on urinary chemistry and we tested it on calcium oxalate crystallization in natural urine.

METHODS: The formation of crystals is induced by the addition of the oxalate and calcium solution.

Optical density (OD) is measured in a closed system at physiological conditions. The effects of the various juices of lemon, was evaluated by the addition of $50 \mathrm{ml}$ of juice. A male volunteer with no history of kidney stone participated in this study, by lemon juice ingestion. The $\mathrm{pH}$, concentration of oxalate, calcium and citrate were determined before and after ingestion and urine was freshly analyzed by microscopy.

RESULTS AND CONCLUSIONS: In synthetic urine, the inhibition rate of calcium oxalate crystallization increases gradually with the lemon juice concentration. In natural

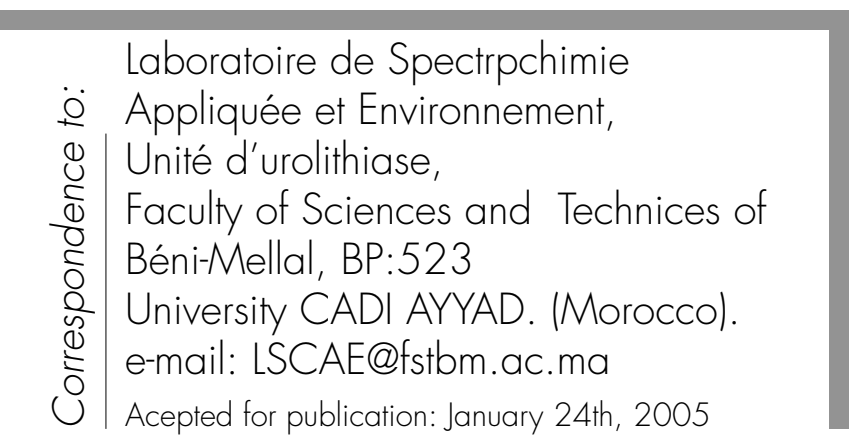

urine, we noted that the kinetics of crystallization of calcium oxalate, before and after ingestion of lemon juice, are comparable. In vivo, after ingestion, a small increase in mean urinary $\mathrm{pH}$ (from $6.7 \pm 0.1$ to $6.9 \pm 0.1$ ) was noted. Indeed, oxalate calcium means and citrate excretion increased during this period with 33. $41 \%, 6.85 \%$ and 3. 53\% respectively. This increase in the oxalate excretion is probably explained by the conversion of the exogenous ascorbic acid contained in the lemon juice. These results show that the lemon juice presents an important inhibitory effect in vitro. The ingestion of the lemon juice seems to dissipate a effect of great quantity of citrates which in turn increases the excretion of oxalates. The presence of these two elements simultaneously: citrate and oxalate compensate for their opposite effect.

Keywords: Urinary lithiasis. Epidemiology. Lemon juice. In vitro. In vivo.

Resumen.- OBJETIVOS: La variedad de resultados experimentales obtenidos en el estudio del efecto del jugo de cítricos en la litogénesis urinaria nos llevó a su efecto in vitro e in vivo. El estudio in vitro se basa en un método de turbidometría de la cristalización de oxalato cálcico. En vivo, estudiamos el efecto del consumo de jugo de limón en la bioquímica urinaria y evaluamos el efecto sobre la cristalización de oxalato cálcico en orina natural.

MÉTODOS: La adición de una solución de oxalato y calcio induce la formación de cristales. La densidad óptica se mide en un sistema cerrado en condiciones fisiológicas. Los efectos de los diferentes jugos de limón fueron evaluados añadiendo $50 \mathrm{ml}$. Un voluntario sano, 
sin historia previa de cálculos renales participó en el estudio mediante la ingestión de jugo de limón. Se determinaron el pH y las concentraciones de oxalato, calcio y citrato antes y después de la ingestión, analizándose la orina fresca al microscopio.

RESULTADOS Y CONCLUSIONES: En la orina sintética, el porcentaje de inhibición de la cristalización de oxalato cálcico aumentó gradualmente con la concentración de jugo de limón. En la orina natural, notamos que las cinéticas de cristalización del oxalato cálcico antes y después de la ingestión del jugo de limón son comparables. In vivo, después de la ingestión se aprecia un ligero aumento del $\mathrm{pH}$ urinario medio /desde $6.7 \pm 0.1$ a $6.9 \pm 0.11$. De hecho, las concentraciones de oxalato cálcico y la excreción de citrato aumentaron durante este periodo el $33.41 \%, 6.85 \%$ y $3.53 \%$ respectivamente. Este aumento de la excreción de oxalato se explicaría probablemente por la conversión del ácido ascórbico exógeno contenido en el jugo de limón. Estos resultados muestran que el jugo de limón presenta un importante efecto inhibitorio in vitro. La ingestión del jugo de limón parece disipar el efecto de gran cantidad de citratos, un aumento de la excreción de oxalato. La presencia de estos dos elementos simultáneamente, citrato y oxalato, compensa sus efectos opuestos.

Palabras clave: Litiasis urinaria. Epidemiología Jugó de limón. In vitro. In vivo.

\section{INTRODUCTION}

In addition to promoter's substances, the urine contains many molecules that are able to be opposed by various mechanisms at the various stages of the lithogenesis [3]. The identification of the natural substances which could be endowed with interesting therapeutic properties in the prevention of the urinary lithiasis seems significant and could contribute to the search for solutions for lithiasics $[4,5]$. The problem arises from the complexities of manipulating dietary variables, the lack of relevant randomized controlled studies, the incomplete description of affected urinary chemistry and methodological issues of measurement.

In our epidemiological study in Tadla- azila area very known by its high production of the citrus we showed that the incidence and chemical composition of urolithiasis reflects the nutritional practice in this populations $[1,2]$.
Other epidemiological databases study $(6,7)$ have examined the effects of various beverages on risk for first episode of nephrolithiasis and an unexpected finding in both studies was the increase risk of nephrolithiasis associated with increasing intake of grapefruit juice. Other [5], showed the ingestion of grapefruit juice offsetting change in urine chemistry not leading to change in calculated supersaturation and not changing lithogenicity. The result didn't demonstrate an effect of grapefruit juice for increasing lithogenicity [5].

The study of the inhibiting capacity will have to be undertaken as well in vitro as in vivo in order to check theses assumptions. The use of some natural substances as an alternative is much more spread in these areas; the study of the inhibiting effect of these substances on the lithiasis formation, will allow to evaluate their effectiveness.

\section{MATERIALS AND METHODS}

\section{A- Turbidimetric study}

The model used to follow the calcium oxalate crystallization in supersaturated aqueous solution, based on the uninterrupted turbidimetric analysis, in a closed system at $37^{\circ} \mathrm{C}$ (Figure 1).

The turbidimetric kinetics were measured by means of a spectrophotometer SHIMADSU 160A, allowing the kinetic study programs, regulated wavelength is at $620 \mathrm{~nm}$. Quartz cell covered with a metal sheath thermostated (thermostated water current). The agitation is maintained using a magnetic bar $(5 \times 2 \mathrm{~mm})$ at 300 t.p.m

The crystallization is obtained by mixture of 2 solutions $C$ and $D$ of the synthetic urine. Their chemical compositions will be given below.

\section{A-1 Calcium oxalate crystallization in synthetic urine.}

A volume of $1,5 \mathrm{ml}$ of $\mathrm{C}$ solution is transferred into a 10-mm light-path cuve in cell. The formation of the crystals is induced by the addition of $1,5 \mathrm{ml}$ of the D solution, freshly prepared.

The synthetic urine supersaturated by calcium oxalate $\left(\left[\mathrm{Ca}^{++}\right]=7 \times 10^{-3} \mathrm{M}\right.$

[oxalate] $=2 \times 10^{-3} \mathrm{M}$ ) is prepared by mixture of equal volume of $C$ and $D$ solutions.

$\mathrm{C}$ solution contains $\mathrm{Na}_{2} \mathrm{SO}_{4} 1 \mathrm{1OH}_{2} \mathrm{O} 1,93 \times 10^{-2}$ $\mathrm{M}, \mathrm{Mg} \mathrm{SO}_{4} 7 \mathrm{H}_{2} \mathrm{O} 5,92 \times 10^{-3} \mathrm{M}, \mathrm{NH}_{4} \mathrm{Cl} 8,67 \mathrm{X}$ $10^{-2} \mathrm{M}, \mathrm{KCl} 0,163 \mathrm{M}$ and $\left[\mathrm{Ca}^{++}\right]=7 \times 10^{-3} \mathrm{M}$.

The $D$ solution contains $\mathrm{NaH}_{2} \mathrm{PO}_{4} 2 \mathrm{H}_{2} \mathrm{O} 1,54$ 
$\times 10^{-2} \mathrm{M}, \mathrm{Na}_{2} \mathrm{HPO}_{4} 12 \mathrm{H}_{2} \mathrm{O} 1,56 \times 10^{-2} \mathrm{M}, \mathrm{NaCl}$ $0,223 \mathrm{M}$ and [ oxalate ] $=2 \times 10^{-3} \mathrm{M}$.

The $\mathrm{pH}$ of the mixture of solutions is adjusted at 5,6.

Optical density (OD) is measured over $90 \mathrm{~min}$. During this time, several kinetic parameters of the reaction are considered, namely the induction time "Ti" and the "turbidity slope". Ti corresponds to time between the addition of oxalate and the moment at which the growth is experimentally measurable $(2.5 \%$ of the maximal $O D$ value). Both parameters can be analyzed in the presence and absence of additives for identical initial calcium and oxalate concentrations.

\section{A-2 Experimental tests}

The effects of the various juices of lemon, were evaluated by the addition of $50 \mu$ l of each juice at different concentrations. Then, we added $1,5 \mathrm{ml}$ of the $D$ solution. For the various concentrations, the percentage of inhibition produced by the additions is calculated by $\{1-[\mathrm{Ti} / \mathrm{Tc}]\} \times 100$; (Figure 1)

$\mathrm{Ti}$ : the turbidity in the presence of inhibitors and Tc: the turbidity in control experiments. The average of the values is obtained after 6 tests. (Vicinity of 2.33\% of the maximum value).

\section{B- In vivo study}

One 28 years old healthy male volunteer with no history of kidney stone participated in the study. The subject was receiving no drugs and was not taking any multivitamins or calcium supplements during the study period. During the control period he drank 300 $\mathrm{ml}$ of tap water at least three times daily for five days. In the second period, he drank $300 \mathrm{ml}$ of natural lemon juice three times daily (at $7 \mathrm{~h}, 13 \mathrm{~h}$ and $20 \mathrm{~h}$ ). Other than this water or lemon juice ingestion the subject ate a regular diet. They were instructed to maintain a relatively constant dairy intake during the control and experimental periods. First morning urine was collected at 7h30 min of the morning during the control and experimental period. We measured the $\mathrm{pH}$ and we

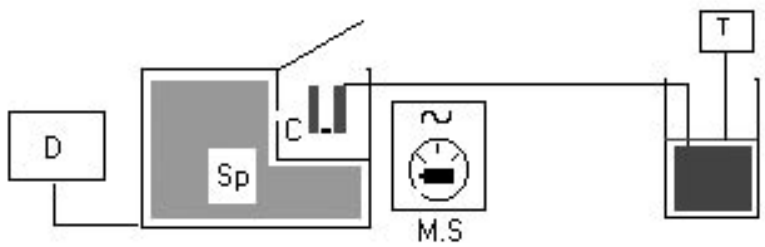

FIGURE 1. Model used for the study of calcium oxalate crystallization in-vitro. analyzed immediately urine samples by polarised light microscopy.

\section{B-1 Dosage of various elements in natural urine}

The concentrations of oxalate, calcium and citrate were determined before and after ingestion of juice. The citrate and calcium were determined by a spectrometric method. The pyridine and anhydride acetic were the reactants used to determine a concentration of citric acid at $428 \mathrm{~nm}$. The concentration of calcium was determined at $620 \mathrm{~nm}$. The oxalate was determined by enzymatic method (biorel).

$0.2 \mathrm{~g}$ of sodium azide was added to the $30 \mathrm{ml}$ of urine sample to prevent bacterial overgrowth and stored at $+4^{\circ} \mathrm{C}$ for an ulterior use.

The formation of the calcium oxalate crystals is induced by the addition to $3 \mathrm{ml}$ of natural urine (diluted) from control and experimental periods of a $100 \mathrm{ul}$ of freshly prepared solution of sodium oxalate $5.10^{-3} \mathrm{M}$. The OD is measured for $1 \mathrm{~h} 40 \mathrm{~min}$.

\section{B-2 Microscopy}

The morphology and the nature of the urinary crystals were examined during the crystallization by polarized light microscope OLYMPUS BX41. The identification was carried out during 90 minutes. The estimate of the number of crystals was determined by counting at the naked eye.

\section{RESULTS}

The amount of crystal formed, as measured by the turbidity of the solution, gradually increased with time until a maximum was reached.

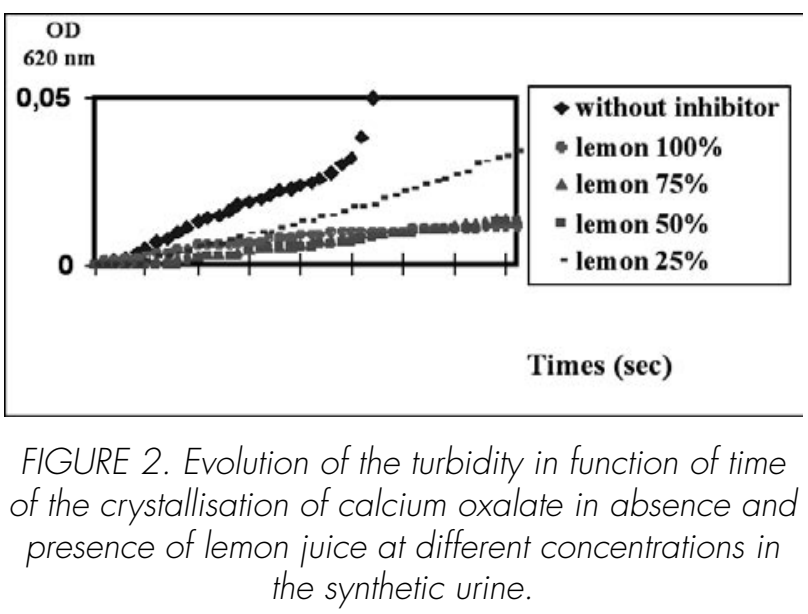


The mean induction time was more than 120 min. The turbidity slope was determined with good reproducibility ( $\mathrm{n}=6 \mathrm{CV}=5 \%$ ). A typical curve of calcium oxalate crystallization using turbidimetric measurement without inhibition in the supersaturated solution of calcium oxalate in synthetic urine was shown in Figure 2.

In synthetic urine, the inhibiting effect of lemon juice with respect to the calcium oxalate crystallization was evaluated. So, we notice that the percentage of inhibition increases gradually with the lemon juice concentration. With a concentration of $25 \%$, the inhibiting capacity of lemon is significant and presents a value almost comparable to that of pure juice [Figure 2].

In natural urine, the formation of the calcium oxalate crystals is induced by the addition, to $3 \mathrm{ml} \mathrm{a}$ $100 \mu$ of freshly prepared solution of sodium oxalate 5.10-3M. Optic density is measured for $1 \mathrm{~h} 40 \mathrm{~min}$. Crude results are schematized in the Figure 3 . We note that the turbidimetric kinetics of crystallization of calcium oxalate, before and after, are comparable.

According to Figure 4, lemon juice ingestion affects oxalate, calcium and citrate excretion, $\mathrm{pH}$ and crystalluria. Indeed, oxalate calcium means and citrate excretion increased during the lemon juice period with $33.41 \%, 6.85 \%$ and $3.53 \%$ respectively.

Different samples were followed by microscopy with various intervals of time, after measuring their $\mathrm{pH}$. We notice that lemon juice ingestion affects the mean urinary $\mathrm{pH}$.

In synthetic urine, in the first minutes, and without inhibitors, we observed a quasi total frequency of small crystals of calcium oxalate monohydrate (COM) the dimension of which rapidly increasing

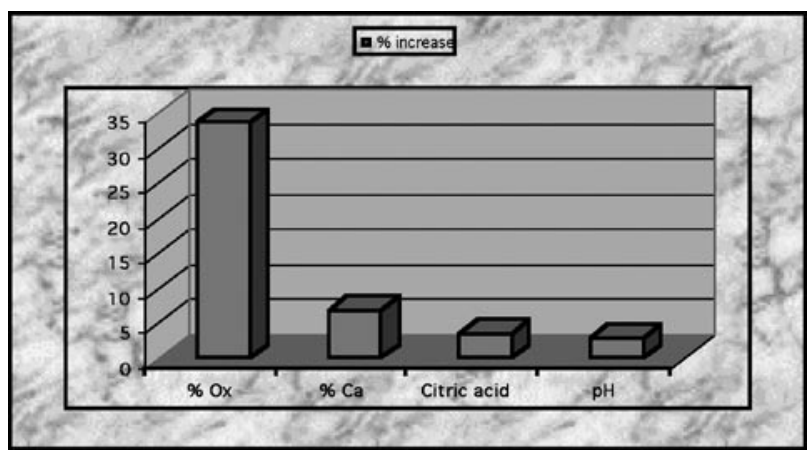

FIGURE 3. percentage of increase of some urinary parameters after ingestion of lemon juice. and some aggregates of COM. A few minutes later, we observed some crystals of calcium oxalate dihydrated (COD)and trihydrate(COT). In natural urine, during the control period, we observed a limited number of crystals of calcium oxalate mono- and di-hydrated and some aggregates of COM and COD.

In the presence of inhibitors, the distribution and frequency seem were not affected. However, for a more precise study, we must call upon a more powerful microscopy like MEB and MET

\section{DISCUSSION}

There are many potential effects of diet to increase or decrease the risk of nephrolithiais. Kidney stones have been attributed to excessive dietary intake of calcium, oxalate, protein and salt as well as to diminished intake of fluids $[8,9]$.

During these last years, a lot of work was devoted to the evaluation of the inhibiting effect of the citrus juices and even of other products, but these results are discussed. Indeed, two kinds of studies have been commonly used to measure the effect of diet on the risk of stones, including epidemiological studies of diet and risk, and short-term studies of urinary composition in response to changes in dietary intake. Short- term studies of urinary chemistries have demonstrated a decrease in urinary lithogenicity after the ingestion of citrus juices, specifically orange and grapefruit juice. Therefore, it was unexpected when an epidemiological study of men [6] and another of women [7] demonstrated a significant effect of grapefruit juice ingestion increasing the risk of stone formation.

In view of the diversity of results from research on the inhibiting effect of the citrus juices on the one hand, and on the other hand, the richness of our area in these lemon, orange trees..., it seems significant to us to evaluate the effect of these natural substances on the crystallization of calcium oxalate as well in-vitro as in-vivo.

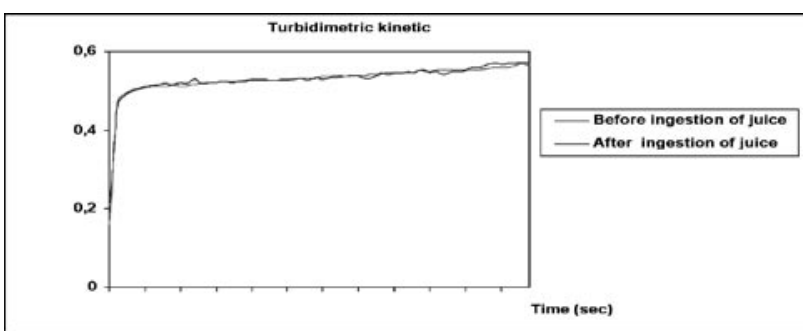

FIGURE 4. Evolution of the mean turbidity for natural urine before and after ingestion. 
For that, we tested the effect of lemon juice on the synthetic and natural urine and its effect on urinary chemical composition.

In a synthetic urine, we noticed an important inhibiting effect of the lemon juice in vitro. The curve of Figure 2 represent the phenomenon of calcium oxalate crystallization. We are interested on the ascending part of the curve which is dependent of apparition of the very small and very many crystals observed by microscopy whose dimension is rapidly increasing. The presence of citrate tends to limit crystallization of calcium oxalate making calcium citrates salts more soluble.

We have observed significant inhibiting effects of the lemon juice at different concentration which increases gradually with this concentration. This difference is related probably to the presence of some elements of an inhibiting capacity contained in these juices. The citrates are known by their inhibiting capacity, and the lemon juice being the richest in this element, it is 5 to 4 times more concentrated in the lemon juice compared to the grapefruit respectively [6 times orange juice] [5].

Several studies showed that citrate reduces the crystallization of calcium salts in vitro $[10,11]$, related to calcium complexation by citrate. But Robertson and scurr [12] noticed that citrate was able to promote nucleation while reducing the crystal growth. Hennequin et al [13] with another model of crystallization seem to confirm this fact even if the main effect of citrate is an effect of complexation of calcium ions. Other studies showed that citrate behaves like an inhibitor of calcium oxalate crystal growth, since it is able in vitro, to fix at the surface of the crystals, to reduce their size and to modify their shape $[14,15]$. In addition, Antinozzi et al. [14] showed that citrate selectively sets on some crystalline faces. Others showed, on in vitro crystallization model, that citrates had a strong activity against crystal aggregation $[16,17]$. The turbidity of the medium gives an account of various stages of crystallization, since it is a function of the number and dimension of the suspended particles.

On in-vivo models, authors such Seltzer et al.[10], Wabner and Pack. [11] noticed that after the ingestion of a total volume of $2 \mathrm{~L}$ of diluted lemon (4 times per a day) and orange 1,2 L respectively, reduced the cristallogenicity risk among patients. Contrarily, other epidemiologic studies $[6,7]$ drawn up on a series of people of both sexes, showed that, the catch of an amount well defined per a day causes the risk of formation of urinary calculus increase, without modifing urinary supersaturation. To examine this contradiction, David gldfarb and Asplin [5] studied the effect of ingestion a grapefruit juice on calcium oxalate crystallization, and a contrarily to the previous studies [12], the grapefruit juice does not have any effect on the increase of the cristallogenicity risk. However, this juice causes a significant increase in the excretion of citrates and oxalates, and citrates are known for their inhibiting effect on crystallization of calcium salts.

For that, we examined the effect of lemon juice ingestion on urinary chemical composition; we demonstrated several effects of lemon juice ingestion on composition of urine chemistry. Lemon juice ingestion caused a small increase in mean urinary $\mathrm{pH}$ from 6.7 \pm 0.1 to $6.9 \pm 0.1$, and a small increase in citrate excretion. Since citrate is an inhibitor of calcium crystal growth and aggregation, this effect would tend to decrease urinary lithogenicity. At least part of the increased citrate excretion is explained by the citrate content of lemon juice, which would appear in the urine after intestinal absorption. In another hypothesis an assumption is questioned about the increase in the excretion of citrates, it is that the effect of citrus juice tends to alkalinize the urine due to the metabolism of potential base in the form of organic anions in citrus juices [5]. Higher urine $\mathrm{pH}$ would directly inhibit tubular citrate reabsorption.

Authors [18] showed that citrate ingestion was amplified by a small and not statistically significant decrease in calcium excretion. Calcium excretion declines with citrate supplementation due to the effect of increased urinary $\mathrm{pH}$ to stimulate calcium reabsorption and the effect of alkalization to decrease reabsorption. Contrarily in our case, we noted a small increasing of calcium which is difficult to be explained.

We also observed a significant increase in oxalate excretion. The $33.4 \%$ observed increase in oxalate excretion is comparable to the $26 \%$ and $35 \%$ increase noted respectively in a study of grapefruit and orange juice ingestion [1 1]. This increase in the oxalate excretion is explained by the conversion of the exogenous ascorbic acid contained in the lemon juice and the oxalate content of lemon juice, is uncertain [11].

If urinary oxalate excretion is an independent risk for stone formation that supersedes supersaturation, the increase in oxalate excretion noted after lemon juice ingestion may account for the effect of this juice on stone incidence. Such a view remains controversial and unproved [19].

The study of oxalocalcic crystallization in the natural urine, before and after ingestion of the lemon 
juice, seems not to affect kinetic crystallization. The difference between the graphs is not very clear, which shows that supersaturation is not affected. That can be to explain only by the fact why the strong excretion of oxalates is compensated by the excretion of the inhibiting elements.

\section{CONCLUSION}

These various results show that lemon juice presents an important inhibitory effect in vitro due to the effect of citrate. However, in vivo the inhibitory effect is not clear, the mode of action being related to its chemical composition.

The ingestion of lemon juice seems to dissipate the effect of a great number of citrates, which in turn increase the excretion of oxalates. The presence of these two elements simultaneously: citrate and oxalate compensate for their opposite effect.

Considering these actions, it seems significant to evaluate separately to us the effects of various compounds contained in lemon on the crystallization of calcium oxalate as well in vitro as in vivo in order to consider their therapeutic potentialities and their clinical interest for the lithiasics.

\section{REFERENCES AND RECOMENDED READING}

\section{("of special interest, ${ }^{* *}$ of outstanding interest)}

**1. OUSSAMA, A.; HILMI, A.; KZAIBER, F. y cols.: "Analyse des calculs urinaires de l'adulte dans le moyen Atlas Marocain par spectrophotométrie infrarouge a transformée de Fourrier". Prog. Urol., 10: 404, 2000.

*2. OUSSAMA, A.; HILMI, A.; KZAIBER, F. y cols.: "Analyse des calculs urinaires de l'enfant au Maroc par spectrophotométrie infrarouge à transformée de Fourier". Ann Urol., 34: 384, 2000.

*3. DAUDON, M.; COHEN-SOLAL, F.; JUNGERS, P. y cols.: "Mécanismes de la lithogenèse et de la cristallurie". Biologie \& Santé, 1: 50, 2000.

*4. ATMANI, F.; KHAN, S.R.: “ Effects of an extract from Herniaria hirsuta on calcium oxalate crystallization in vitro". BJU International, 85: 621, 2000.

**5. GOLD FARB, D.S.; ASPLIN, J.R.: "Effect of grapefruit juice on urinary lithogenicity". J. Urol., 166: 263,2001 .
*6. CURHAN, G.C.; WILLET, W.C.; RIMM, E.B. y cols.: "prospective study of beverage use and risk kidney stones". Am. J. Epidemiol., 43: 240, 1996.

*7. CURHAN, G.C.; WILLET, W.C.; SPEIZER, F.E. y cols.: "Beverage use and risk for kidney stones in women". Ann Intern. Med., 128: 534, 1998.

*8. GRASES, F.; GARCIA-FERRAGUT, L.; COSTA-BAUZA, A. y cols.: "Study of the effect of different substances on the early stages of papillary stone formation". Neph., 73: 561, 1996.

*9. CURHAN, G.C.; WILLET, W.C.; RIMM, E.B. y cols.: "A prospective study of dietary calcium and other nutrients and the risk of symptomatic kidney stones". N. Engl. J. Med., 328: 833, 1993.

**10. SELTZER, M.A.; LOW, R.K.; McDONALD, M. y cols.: "Dietary manipulation with lemonade to treat hypocitraturic calcium nephrolithiasis". J. Urol., 156: 907, 1996.

**11. WABNER, C.L.; PAK, C.Y.C.: "Effect of orange juice consumption on urinary stone risk factors". J. Urol., 149: 1405, 1993.

*12. ROBERTSON, W.G.; SCURR, D.S.: "Modifiers of calcium oxalate crystallization in urine. I. Studies with a continuous crystallizer". J. Urol., 135: 1322, 1986.

**13. HENNEQUIN, C.; LALANE, V.; DAUDON, M. y cols.: "A new approach to studying inhibitors of calcium oxalate crystal growth". Urol. Res., 21: $101,1993$.

**14. ANTINOZZO, P.; BROWN, C.M.; KHAN, S.R. y cols.: "Inibitory action of citrate on calcium oxalate monohydrate crystal nucleation and growth". Proceedings of the VIIth International Symposium on Urolithiasis cairns, 115: 24, 1992.

**15. GRASES, F.; COSTA-BAUZA, A.: "Study of factors affecting calcium oxalate crystalline aggregation”. Br. J. Urol., 66: 240, 1990.

*16. KOK, D.J.; PAPAPOULOS, S.E.; BLOMEN, L.J. y cols.: "Modulation of calcium oxalate monohydrate crystallization kinetics in vitro". Kidney Int., 34: 346, 1988.

*17. KOK, D.J.; PAPAPOULOS, S.E.; BUVOET, O.L.M.: "Excessive crystal agglomeration with low citrate excretion in reccurent stone-formers". Lancet. I., 1056, 1986.

*18. BUSHINSKY, D.A.; KYRIEGER, N.S.: "Regulation of bone formation and resorption". Kidney stones: Medical and surgical management. Edit by F.L Coe, MJ. Favus C.Y.C. Paket al philadelphia; Lippinott-Raven, 239, 1996.

*19. CURHAN, G.C.: "Calcium is the most important risk for idiopathic calcium oxalate stone formation". Proceeding of the 9th International symposium on urolithiasis. Edit by A. L. Rodgers, B. E. Hibbert, B. Hess et al ; Capetown, South Africa: University of Capetown, 295, 2000. 